\title{
The culture of justice: reflections on punishment in Dostoevsky's The Idiot
}

\author{
Andrea Zink
}

Published online: 27 October 2010

(C) Springer Science+Business Media B.V. 2010

\begin{abstract}
The article investigates Dostoevsky's juridical discourse and demonstrates that the apologist of the Russian soul had a genuinely European mind. In his novel The Idiot in particular, in which the death penalty and imprisonment are explored, Dostoevsky unmasks - more radically even than Victor Hugo- the supposedly civilised and lenient forms of modern criminal justice. Dostoevsky's criticism is ahead of its time; his arguments resemble those subsequently put forward by Foucault. A comparison with Anatoly Pristavkin's report on postCommunist crime and jurisdiction underscores the topicality of these reflections.
\end{abstract}

Keywords Death penalty - Imprisonment - Russian soul - Western civilisation · Psychology $\cdot$ Writing $\cdot$ Painting $\cdot$ Compassion

\section{Introduction}

The abolition of the death penalty has been the subject of debate throughout Europe from the Enlightenment through to the twenty-first century. This is generally regarded as a sign of cultural and civilizational progress, as reflected in the following advice from a Russian citizen to the Pardons Commission established under El'cin:

The abolition of the death penalty is only possible in a civilised society, which ours is not. ${ }^{1}$

\footnotetext{
1 Pristavkin (2000а, 419): “Отмена смертной казни возможна в цивилизованном обществе, каковым наше не является."
}

Translated from German by Joy Titheridge.

\footnotetext{
A. Zink $(\bowtie)$

Slavisches Seminar, Universität Basel, Nadelberg 4, CH-4051 Basel, Switzerland

e-mail: andrea.zink@unibas.ch
} 
Societies without the death penalty are not the only ones to consider themselves civilised. So too do the advocates of state retribution, including the author of the above-cited letter. After all, he makes a distinction between his own civilised mind and his 'barbarian' surroundings. Although the abolition of the death penalty is not yet possible he wants the 'spectacle' to be carried out as 'humanely' as possible, in other words, quickly, and in secret. Death is not to be preceded by martyrs. It must be hidden from public view.

The perfection of killing techniques produces what is considered to be civilization or a civilized society. To put it clearly, seen from the angle of a capital punishment history, civilization is perfect executing. (Martschukat 2005, 61-62)

Regardless, then, of whether the death penalty is opposed or calls are made for it to be carried out "humanely", civilised citizens are no longer to be exposed to public displays of corporal punishment. The spectators' sense of shame at these demonstrations of antediluvian justice is too great a risk. The people may pity the condemned criminal, or even join in collective protest against the punishment. From the 19th century onwards, such demonstrations of the 'wrath of God' became problematic, or at least risked missing their objective, namely the perpetuation of state power. $^{2}$

The European elite has expressed its discomfort with the death penalty in a variety of ways. The first to give voice to this sense of unease was Cesare Beccaria. In keeping with the objective, mathematical spirit of the Enlightenment, Beccaria reasons that prison sentences can be calculated more precisely. ${ }^{3}$ Subsequent writers and philosophers, meanwhile, see themselves rather as the conscience of their nation or society. This is also true of Russia. ${ }^{4}$ Victor Hugo's Le dernier jour d'un condamné found many receptive and kindred spirits in the Russian elite. This book resonated particularly profoundly with Dostoevsky. On 22 December $1849^{5}$ he himself stands on St. Petersburg's Senate Square as a condemned man, expecting to be executed by firing squad within a matter of minutes. He understands all too well the mental anguish of the condemned. Immediately following the mock execution, he tells his brother that Hugo's first-person narrator had articulated precisely his own sensations. ${ }^{6}$ Thus Dostoevsky takes his place in the pan-European discourse on

\footnotetext{
${ }^{2}$ On the complementary development of public criminal law and state regulation, with public punishment replacing the old system of fines, cf. Wesel (1997, 333-339).

3 Beccaria (Dei delitti $i$ delle penne, 1764) argues that prisons allow guilt to be punished according to degree, i.e. measured in time. See Wesel (2004, 239).

${ }^{4}$ On the role of writers in the Russian Presidential Pardons Commission, see Pristavkin (2000a, 63-64). They were appointed to the commission for two reasons: because they hold authority and because they oppose the death penalty.

5 Date according to the Julian calendar.

6 The comparison is also apt because Hugo's narrator, like Dostoevsky, is a member of the upper classes and endowed with a sensitive soul. The reader never learns of his crime. It seems almost certain that he has done nothing wrong at all. His conviction could be due to a miscarriage of justice. See also Knapp (1998, 15).
} 
culture and civilisation according to which the death penalty is inhumane, and the condemned man worthy of pity.

And yet Dostoevsky would not be Dostoevsky if he clung doggedly to his ideas and considered himself the unswerving champion of an enlightened humanism. Indeed, the reception of Dostoevsky in Western Europe comes to a different conclusion. Here the emphasis is above all on Dostoevsky's national contribution. This is the focus of scholarship ranging from the readings of Merežkovskij (1909) and Moeller van den Bruck (1918) ${ }^{7}$ to recent studies by Hudspith (2004) and others. For (Western) Europeans, Dostoevsky is a genuinely Russian, religious writer, the poet of a uniquely Russian path. And although Mikhail Bakhtin debunked this interpretation some time ago (Bakhtin 1929, 1963) there do exist a number of convincing reasons for this national interpretation of Dostoevsky's work.

\section{Western civilisation-Russian soul}

By the time of his return from Siberia, Dostoevsky is on a quest for the Russian people and the Russian soul. ${ }^{8}$ He publishes a number of articles dealing with the national theme in his one-man journal A Writer's Diary. And it is with the Russian soul that Dostoevsky makes a stand against European civilisation. For him, the soul is a genuinely Russian, anti-civilising element.

And is it not a curious phenomenon that [...] those Russians who most consider themselves Europeans, who are known in Russia as "Westerners", [...] are precisely the ones who join the negators of civilization, its destroyers; who side with the "extreme left"; and that in Russia this causes no surprise whatsoever $[\ldots]$ ?

[...] is there not revealed in this the protesting Russian soul, to which European culture [...] has always [...] been hateful and has always been felt alien to the Russian soul? (Dostoevskij 1973a, 352) ${ }^{9}$

\footnotetext{
7 Merežkovskij's, Moeller van der Bruck's and Thomas Mann's readings of The Devils are analysed by Weiß (2005).

8 Dostoevsky's interest in the characterisation of Russianness dates back to his Winter Notes on Summer Impressions (1863). Here, however, his main argument is the concept of character. In his view, the Russian character stands in agreeable contrast to the French individualistic, morally saturated bourgeois consciousness. But even the Winter Notes invite the question whether Dostoevsky himself does not reproduce, in exaggerated terms, the very qualities of the French that he criticises-in style and in perspective. His Winter Notes are conceived as a reckoning with Europe, and yet they are characterised by a highly subjective style and moral reasoning-qualities, in fact, which he himself attributes to the French. Dostoevsky does not appear in the least wild, restive, or patriarchal, as he characterises the Russians, and as a Russian text was thus supposed to be (Dostoevskij 1973b, 56-57, 74-82, 84-85).

9 Dostoevskij (1981b, 39): “как не любопытно такое явление, что те-то именно русские, которые наиболее считают себя европейцами, называются у нас “западнками” [...] скорее всех и примыкают к отрицателям цивилизации, к разрушителям её, к “крайней левой” и что это вовсе никого в России не удивляет [...]?

[...] не сказалась ли в этом факте [...] протестующая русская душа, которой европейская культура была всегда [...] ненавистна и во многом, слишком во многом сказывалась чужой русской душе?".
} 
It is only superficially a paradox, he writes, that the Russian soul manifests itself in the activities and theories of the so-called "Westernizers." But in the same entry, he is compelled to admit that European civilisation is not only threatened by Russians, but also by its local population, the Western European lower classes. Their "souls" do not even merit a mention. And so we may ask whether Dostoevsky does not find in the anti-civilising tendency of the Westernizers (who were, after all, educated) a pretext for locating the Russian nation outside the peasantry, that is, the Russian soul outside the national body.

His writings, whether journalistic or artistic, are known for their ambivalence. ${ }^{10}$ As much as his sympathies lie with the people, Dostoesky is aware that neither he nor the Russian intellectual elite actually know them.

And yet, to all of us, the people are still a theory and they continue to loom as an enigma. We all, lovers of the people, regard them as a theory, and it seems that none of us likes them as they really are, but as each one has represented them to himself (Dostoevsky 1973, 204). ${ }^{11}$

This is not the first time Dostoevsky has been beset by doubts about the soul of the people. Above all, he doubts the possibility of a harmonious relationship between peasants and intellectuals. These misgivings arise as a result of his experience in the Omsk prison camp, which he writes about in The House of the Dead. The aristocratic narrator, Gorjančikov, has to admit that the criminals among the peasantry (who form the majority of the prisoners) are well-acquainted with corporal punishment and accept it without a murmur. He himself, the educated observer, is exempt from these punishments and can only speculate about the psychological effects of being beaten. Although Gorjančikov never tires of pointing out the criminals' childlike disposition, the novel also conveys the impression that some of the prisoners can be extremely brutal. ${ }^{12}$ The embedded narrative 'Akul'kin muž' is eloquent evidence of this. It seems that the narrator and, with him, the author Dostoevsky want to connect with the people, ${ }^{13}$ yet they remain apart. Their status, their education, their morality, and their psychological acuity preclude such kinship.

\footnotetext{
${ }^{10}$ Vasenna (2007) cogently identifies the persuasion strategies Dostoevsky uses in the Diary to reach his readers and address their concerns. He is generally successful, with only a few exceptions. The extent to which Dostoevsky's journalistic writings enter into a dialogue with his readers decreases following his arrest and exile. At the same time, there is an increase in the intentional manipulation of his audience, which largely achieves its ends.

11 Dostoevskij (1981a, 44): “Однако народ для нас всех-все ещё теория и продолжает стоять загадкой. Все мы, любители народа, смотрим на него как на теорию, и, кажется, ровно никто из нас не любит его таким, как он есть на самом деле, а лишь таким, каким мы его каждый себе представили."

12 See also Zink (2005).

13 Gorjančikov hopes to mediate between the intellectual and common criminals. According to Sergeyev, this strategy of Dostoevsky's experienced a revival during perestroika, together with its less palatable consequences. "The tradition of Dostoevsky's man from the underground came back to life. The fight for human dignity in prison was the main theme of a great number of dissident publications. [...] The new rationality, supported by the ideology of perestroika, produced a dramatic effect by eradicating the psychological borderline between freethinking and crime, so that a criminal began to be regarded as a hero" (Sergeyev 1998, 94-95).
} 
The subjects of prosecution and imprisonment were to absorb Dostoevsky for the rest of his life. They bear a close relation to his yearning for the people-a yearning plagued by doubts when he contemplated the foreignness and uncivilised manners of his fellow men. Dostoevsky's juridical discourse is testimony to the tension between the values of a mind informed by European civilisation and equipped with astonishing psychological skill, and the people, who may have a different conception of crime and punishment. For Dostoevsky, jury verdicts provide a constant incentive to engage with the people and question one's own notions of guilt and expiation. $^{14}$

European legal culture and national aspirations also come into conflict in The Idiot. Here Dostoevsky's search for the Russian soul is enlarged upon for the first time, and the Russian soul is clearly expected to weaken European civilisation. ${ }^{15}$ But this vision could in fact be the product of a consciousness informed by Western civilisation. It is the brainchild of Prince Myškin, a hero who is only too familiar with European problems, arguments, and emotions.

He was beginning, however, to believe passionately in the Russian soul. Oh, he had endured so much, so much that was quite new to him in those six months, and unlooked-for, and unheard-of, and unexpected!

But another man's soul is murky, and the Russian soul is murky; it is so for many. Here he had long been getting together with Rogožin, close together, together in a "brotherly" way_but did he know Rogožin? And anyhow, what chaos, what turmoil, what ugliness there sometimes is in all that (Dostoevsky 2003, 228)! ${ }^{16}$

It would appear from this citation that the Russian soul has little in the way of positive qualities. It is murky and impenetrable; Myškin believes in the soul. This is all readers are told. According to the logic of the text, Rogožin alone appears to possess a Russian soul. Here we have a character who represents the prince's subconscious, as a number of studies have pointed out. ${ }^{17}$ Rogožin never appears alone. He is always in the company of Myškin (Schmid 1999), and his character is completely different to that of the trusting, Christ-like prince. Of merchant stock,

\footnotetext{
14 Dostoevsky's complex and ambivalent criticism of Western forms of justice is examined in Rosenshield (2005). In his discussion of the jury trial in the Brothers Karamazov, Rosenshield demonstrates that it is in particular his own psychological methods, which he had applied to real trials in Diary of a Writer, that Dostoevsky is questioning here. In his last novel, Dostoevsky struggles to find a form of Russian justice independent of this psychology.

15 Work on the novel was fuelled by Ivan Turgenev, whose Western manners and arrogance towards Russia had made a poor impression on Dostoevsky in Baden-Baden. On this background, see Knapp (1998, 232-235). Dostoevsky was already engaged in the critique of civilisation at this time. However, he still had great hopes that the judicial reform would have a positive impact on the people. See Knapp (1998, 229).

16 Dostoevskij (1973a, 190): "В руссую душу, прочем, он [Мушкин] начинал страстно верить. О, много, много вынес он совсем для него нового в эти шесть месяцев, и негаданного, и неслыханного, и неожиданного!

Но чужая душа потёмки, и русская душа потёмки, для многих потёмки. Вот он долго сходился с Рогожиным, “близко” сходились, братски сходились,-а знает ли он Рогожина? А впрочем, какой иногда тут, во всём этом хаос, какой сумбур, какое безобразие!”.

17 For an in-depth study, see Dalton (1979). A briefer outline of this idea can be found in Dalton (1989).
} 
Rogožin is unpredictable and unrestrained. The workings of his mind are never revealed. This reticence on the part of the author is only logical. If Rogožin is the result of a psychoanalysis of Myškin, he cannot in turn be analysed himself. The contemplative Myškin, on the other hand, the clear and bright, but also mentally ill protagonist, belongs to another dimension. According to the antagonism suggested by Dostoevsky himself, Myškin could be described as an extremely progressive Western soul. And, too, the novel in its entirety could be seen as the expression of a profoundly European, psychologically motivated search for the dark recesses of our own minds. This search is projected onto a foreign region, not unlike the Orient of the orientalists (Said 1979). ${ }^{18}$ Thus Russianness appears exotic, wild, dark, while the soul manifests itself on the very opposite side. This possessing of a soul, the sign of an advanced civilisation, is expressed in Myškin's reflections on the death penalty - a form of punishment, moreover, that is typical of Western European criminal justice, but not that of Russia.

\section{Death penalty and imprisonment}

The death penalty was abolished in Russia under Empress Elizabeth in 1744. Although it was reintroduced just a few years later, it was seldom employed prior to 1905. The authorities particularly refrained from carrying out death sentences following the judicial reform of 1864 (Kvashis 2002). ${ }^{19}$ Serious political crimes were of course exempted from this arrangement. Dostoevsky knew about the exceptions from personal experience. In 19th century Russia, the death penalty was reserved for certain persons only, namely political assassins, generally of the upper classes. In the West, on the other hand, it was still practised frequently. Russian writers travelling in the West, among them Tolstoy and Turgenev, ${ }^{20}$ were appalled. At this time and over the course of many long years and indeed centuries, Russia boasted a different penal system. Russia, it would appear, had no need for the death penalty. The Russian penal system can be summed up in a single word: Siberia. And compared with the death penalty, Siberia is both more pragmatic and more corporal. There is no need for any complex psychological reasoning about Siberia, that is to say, about the convicts in the Siberian camps doing hard labour and often experiencing physical abuse. Those in power are not interested in their mental states, they are taken care of, as it were, they are occupied and far removed. The same does not apply to the criminals placed under the guillotine and publicly

\footnotetext{
18 Wolff (1994) draws similar conclusions with respect to Eastern Europe, with the difference that, from a Western perspective, Eastern Europe can still develop. It is only half-wild, half-foreign, much like a child.

19 See also Pristavkin (2000a, 296): “в прошлом, XIX веке, обозначенном как жестокой, в течение ста лет было казнено что-то трёхсот человек."

20 Tolstoy witnessed a beheading in Paris in 1857 and fled, horrified, to Switzerland. And when the mass murderer Troppmann was executed, also in Paris, Turgenev was among the numerous spectators. The Russian intelligentsia could only shake their heads at the gross excesses of the genteel French. It is conceivable that Prince Myškin's first name and patronymic, Lev Nikolaevič, may derive from Tolstoy's shock, and thus underscore the importance of the subject of the guillotine in The Idiot. On Dostoevsky's reaction to Tolstoy's and Turgenev's experiences, see Jackson (1993, 29-74). The Tolstoy connection is reinforced by Myškin's affinity to Pierre Bezukhov (see Miller 1998, 66).
} 
executed. These criminals are the object of psychology. It is as if Dostoevsky needs the criminal proceedings typical of Western Europe in order to bring out the sensibilities of his characters at all. And Myškin takes up the criminal's cause.

Abroad, in France, the prince had witnessed the spectacle of executions. At the beginning of the novel, he confronts the general's valet with his memories and conjectures.

Think: if there's torture, for instance, then there's suffering, wounds, bodily pain, and it means that all that distracts you from inner torment, so that you only suffer from the wounds until you die. And yet the chief, the strongest pain may not be in the wounds, but in knowing for certain that in an hour, then in ten minutes, then in half a minute, then now, this second-your soul will fly out of your body and you'll no longer be a man, and it's for certain-the main thing is that it's for certain. When you put your head under that knife and hear it come screeching down on you, that one quarter of a second is the most horrible of all. Do you know that this isn't my fantasy, but that many people have said so? [...] Christ spoke of this suffering and horror. No, you can't treat a man like that! (Dostoevsky 2003, 23) ${ }^{21}$

Myškin criticises the replacement of physical punishments with psychological ones, a shift typical of Western Europe. He is particularly censorious of the quick and clean modern executions, a method of killing that is generally equated with a high level of civilisation. He compares guillotining unfavourably with the very physical executions of former times, such as impalement, which made heroes of the tormented criminals (Dostoevsky 2003, 522-523; Dostoevskij 1973a, 432-433). Myškin's civilisation critique is well ahead of its time. But the Russian penal system cannot present an alternative from this point of view. Developments in Russia were similar, though not identical, to those in Western Europe. As the 19th century progressed, the Russian public was no longer expected to endure the spectacle of punishment (Schrader 1997). The old punishments disappeared. However, corporal punishment was still possible among the peasantry, despite its official abolition in the judicial reform. Theft or other petty crimes were punished with beatings in the so-called volostnye sudy. But the peasants did not suffer agonising pain; no heroes were born on the scaffold. Moreover, to all appearances they were happy with this solution. The difference between a psychologically reasoning elite and the lower classes, who think more pragmatically, becomes very clear when we compare Myškin's reflections with the views of the valet. While Myškin ponders at length the soul, the state of mind, the valet promptly pictures the head flying away:

\footnotetext{
21 Dostoevskij (1973a, 20-21): “Подумайте: если, например, пытка; при этом страдания и раны, мука телесная, и стало быть, всё что от душевного страдания отвлекает, так что одними только ранами мучаешься, вплоть пока умрёшь. А ведь главная самая сильная боль, может, не в ранах, а вот что вот знаешь, наверно, что вот через час, потом через десять минут, потом через полминуты, потом теперь, вот сейчас-душа из тела вылетит, и что человеком уже больше не будешь, и что это наверно; главное то, что наверно. Вот как голову кладёшь под самый нож и слышишь, как он склинет над головой, вот эти-то четверть секунды всего и страшнее. Знаете ли, что это не моя фантазия, а что так многие говорили? [...] О6 этой муке и о6 этом ужасе и Христос говорил. Нет, с человеком так нельзя поступать."
} 
"It's a good thing there's not much suffering", he [the valet] observed, "when the head flies off" (Dostoevsky 2003, 23). ${ }^{22}$

The valet speaks of the effect the punishment has on the body; Myškin is interested in the mind. Thus, for all his criticism of the European process of civilisation, it is to this very civilisation that the prince remains true. Myškin is in fact, as we shall demonstrate, a thinker of a particularly progressive, Western ilk.

The replacement of public displays of torture with psychological punishment, even where this takes the form of the death penalty, is one measure of the progress of European civilisation and has prompted various explanations. Pieter Spierenburg, for example, postulates a general refinement of sensibilities amongst the European populace and a progressive development of their sense of shame (Spierenburg 1984). The violent, public spectacle of punishment is no longer to the public's liking; spectators find it offensive. ${ }^{23}$ But the gradual demise of corporal punishment can also be explained by the interests of an apparently supra-individual, barely identifiable power. The shift from physical to psychological punishment is then just a tactical manoeuvre, a subtle change in the strategy of power. This is Michel Foucault's position (Foucault 1991). ${ }^{24}$ And Prince Myškin appears to subscribe to a synthesis of these two interpretations.

According to Foucault, public torture and, subsequently, corporal punishment were abolished in the 19th century due to the fear of riots. The guillotine was quick and simple. It represented an initial solution to the problem; in a second step it had to be employed behind walls, out of the view of the masses. ${ }^{25} \mathrm{~A}$ similar, indeed a superior solution is the prison. The criminal held in confinement is locked away, individualised, kept under personal surveillance, and able to be reformed. The mind of the offender is now analysed, his mental state moulded, money invested in specialists. According to Foucault, however, this ostensible leniency is in fact the expression of power, a strategy. He believes that even the soul itself is the expression of a mechanism of power. Pity for the criminals follows hard on the heels of this undertaking; its purpose is to keep the prisoners where they are, so that they can continue to be pitied and provided with psychological support. The prison is self-perpetuating.

One hundred years previously, Dostoevsky's hero had already seen through the masked aggression of the modern penal system devised in Western Europe. Myškin exposes the pseudo-humane nature of modernity and points out that physical torture was simply replaced by psychological torture. At the same time, the prince, or Dostoevsky, also subjects his readers to the psychological torture of suspense. There is something voyeuristic about the passage in question. The condescension, the pity felt for the convict is unmasked, but also flaunted. Dostoevsky's novel can in fact be

\footnotetext{
22 Dostoevskij (1973a, p. 20): “-ХХрошо ещё вот, что муки немного,-заметил он [камердинер], когда голова отлетает."

23 Spierenburg's argument goes hand in hand with that of Norbert Elias in The Civilizing Process (Elias 1978-1982).

24 This is Foucault's position in Discipline and Punish. The Birth of the Prison (Foucault 1991).

25 Jürgen Martschukat reasons similarly with regard to developments in Hamburg (Martschukat 2000) and with respect to Europe (Martschukat 2006).
} 
read as an example of the contemporary Western refinement of sensibilities, an example, too, of a power that needs the criminal for its own justification. The prince draws at will on the mind of the criminal; it exerts an irresistible appeal. ${ }^{26}$ But Dostoevsky goes one step further. He not only reproduces the mechanisms of power, he also sees right through them. Like Foucault, he does not stop at the machinery of justice. He recognises forms of imprisonment in familial oppression, such as Nastas'ja Filippovna's relationship to Tockij, (Dostoevsky 2003, 170-171, 350; Dostoevskij 1973a, 143, 289) and in terminal illness. Power, the strategy of modern imprisonment, which is found in schools and hospitals, but especially in psychiatric institutions, is unmasked in The Idiot. The mentally ill Myškin and the consumptive Ippolit, figures on the margins of society, stand in contrast to normal, right-thinking citizens.

Ippolit is condemned to death. His sentence resembles that of a criminal, except for the fact that he cannot determine the exact time of his death. ${ }^{27}$ Ippolit also compares his existence with incarceration; his physical immobility prevents him from leaving the room (Dostoevsky 2003, 412; Dostoevskij 1973a, 342). He refuses to be pitied and vehemently rejects any such demonstrations. In this, too, he proves to be a modern man, on a par at the very least with Nietzsche's unmasking of pity. ${ }^{28}$ Imprisoned, he projects his thoughts onto Mejer's wall, the wall of the opposite house. Mejer's wall takes on the function of paper, of a parchment on which the sick person can inscribe his soul. It represents a record of disease, the written record of the mind of a doomed man:

Yes, that wall of Mejer's can tell a lot! I have written a lot on it. There is not a spot of that dirty wall that I have not learned by heart. That cursed wall! (Dostoevsky 2003, 392). ${ }^{29}$

Ippolit's illness is a death sentence that triggers a psychological analysis, a confession, with which Ippolit confronts his listeners and Dostoevsky his readers over many long pages. His reflections on his illness resemble the reflections of a prison doctor and are in keeping with Foucault's reflections on the Birth of the Prison. And it is perhaps no coincidence that the name of the wall which reflects

\footnotetext{
26 This ambivalence is typical of the nineteenth century and is emphasised by Martschukat $(2006,106)$. In conversation with the Epanchin sisters, Myškin speculates at length about the mind of the criminal in the moments before his execution (Dostoevsky 2003, 62-66; Dostoevskij 1973a, 54-57). The voyeuristic aspect is particularly apparent in this passage. This is also examined by Wagner (1995, 101-103).

27 Ippolit speaks repeatedly of his death sentence (Dostoevsky 2003, 394, 395; Dostoevskij 1973a, 327, 328).

28 In Thus Spake Zarathustra Nietzsche writes: "Verily, I like them not, the merciful ones, whose bliss is in their pity: too destitute are they of bashfulness" (Nietzsche 2009, 80). Cf. Dostoevsky: “... if I hate anyone here [...] you, you Jesuitical, treacly little soul, idiot, millionaire-benefactor, I hate you more than anyone or anything in the world! [...] It was you who drove me into a fit! You've driven a dying man to shame [...]! I'd kill you, if I stayed alive!” (Dostoevsky 2003, 298-299; Dostoevskij 1973a, 249: “... если я кого-нибудь здесь ненавижу [...] вас, вас, иезуитская, паточная душонка, идиот, миллионер-благодетель, вас более всех и более всего на свете! [...] Это вы меня довели до припадка! Вы умирающего довели до стыда [...]! Я убил бы вас, если 6 остался жить!”)

29 Dostoevskij (1973a, 326): “Да эта Мейерова стена может много пересказать! Много я на ней записал. Не было пятна на этой грязной стене, которого бы я не заучил. Проклятая стена!”
} 
these contemplations is Mejer's. There is a close connection between the death penalty, the image, the written word, and the question of the Russian soul, or of Russia's Western character. ${ }^{30}$

Paintings, portraits and the written word

It is not surprising that it falls to Ippolit Terentyev to provide a description of a painting for which readers have been waiting for hundreds of pages. Like Mejer's wall, the painting records the impact of the death sentence. It is Holbein's "Christ in the Tomb," a painting that Dostoevsky had seen on his journey through Basel. Now, in his novel, it hangs in reproduction in Rogožin's home.

This picture portrays Christ just taken down from the cross. [...] this is in the fullest sense the corpse of a man who had endured infinite suffering before the cross, wounds, torture, beating by the guards, beating by the people as he carried the cross and fell down under it, and had finally suffered on the cross for six hours (at least according to my calculation). True, it is the face of a man who has only just been taken down from the cross, that is, retaining in itself a great deal of life, of warmth; nothing has had time to become rigid yet, so that the dead man's face even shows suffering as if he were feeling it now (the artist has caught that very well); [...] Nature appears to the viewer of this painting [...] in the shape of some huge machine of the most modern construction, which has senselessly seized, crushed, and swallowed up, blankly and unfeelingly, a great and priceless being (Dostoevsky 2003, 407408). ${ }^{31}$

Ippolit speaks of the huge machine of modern construction, alluding to the guillotine. But another aspect of modernity is clearly involved here, namely the psychological penetration of the condemned man. In describing the Holbein painting, Ippolit is telling us what is written on Mejer's wall. All of these records of disease, moreover, are accompanied by Western names. Mejer, Holbein and Šnejder - these are the doctors and psychologists at work in The Idiot. ${ }^{32}$ Prince Myškin

\footnotetext{
30 This close connection between imprisonment and writing (often emphasised by ekphrasis, the description of paintings and photographs) is also true of Nastas'ja Filippovna's portrait (Dostoevsky 2003, 349-350; Dostoevskij 1973a, 289). Myškin sees in the portrait a woman imprisoned, emotionally confused; it stirs in him a deep sense of pity.

31 Dostoevskij (1973a, 338-339): “На картине изображён Христос, только что снятый с креста. [...] это в полном виде труп человека, вынесшего бесконечные муки ещё до креста, [...] и наконец крестную муку в продолжение шести часов (так по крайней мере по моему расчёту): Правда, это лицо человека только что снятого со креста, то есть сохранившее в себе очень много живого, тёплого; ничего ещё не успело закостенеть, так что на лице умершего даже проглядывает страдание, как будто бы ещё и теперь им ощущаемое (это очень хорошо схвачено артистом); но зато лицо не пощажено нисколько; тут одна природа. [...] Природа мерещится при взгляде на эту картину в виде [..] какой-нибудь громадной машины новейшего устройства, которая бессмысленно захватила, раздробила и поглотила в себя, глухо и бесчувственно, великое и бесценное существо."

32 Ippolit's terminal illness is also an allusion to Flaubert's Madame Bovary, specifically to Charles Bovary's botched operation on Hippolyte's clubfoot which results in the amputation of the leg (Knapp 1998, 35).
} 
receives treatment in Switzerland, the country where Holbein's painting also hangs. And for Dostoevsky, the true psychologist of the condemned, there is clearly a danger inherent in these forms of Western justice and medicine.

The written word, Derrida tells us, has time. The slowness of the written word draws attention above all to what is missing. ${ }^{33}$ The Holbein painting is not described at first. This hesitation, ${ }^{34}$ or postponement in the Derridean sense, points to another hiatus, another omission in the novel. For where are the images of the Russian God, images that bring out the holiness of their subjects? Icons are only mentioned in passing in The Idiot, they only appear on the periphery (Dostoevsky 2003, 366, 409, 593; Dostoevskij 1973a, 304, 340, 492). And nothing could be more contrary to the Holbein painting than the icons of the Orthodox Church, whose two-dimensionality and schematism accentuate the sacredness of the image and the collective work of the icon painters (Onasch 1996; Benz 1988, 5-20). The Idiot centres instead on a lonely Christ, (Kristeva 1989) the work of an individual artist. The painting fairly exudes the spirit of the Reformation, which likewise accentuates the individual. ${ }^{35}$ Dostoevsky, and with him Prince Myškin, may indeed be in search not only of the Russian soul but also of the Russian God. (Dostoevsky 2003, 546; Dostoevskij 1973a, 453). But this search is driven by a Western consciousness-a consciousness that reasons psychologically, demands individuality, shows pity and despises pity, and which is suffused with the fear of perhaps finding, instead of God, only His death. We are confronted in The Idiot with a world of isolated individuals on the margins of society, with madmen and prisoners of every stripe. Their destinies are not in God's hands but appear to be controlled by sinister forces, a Foucauldian abstract power. This leads us to another connection to writing in the novel.

The novel begins with Myškin's return to Russia. Asked how he proposes to earn a living, he mentions a special talent: $\mathrm{He}$ is a calligrapher. ${ }^{36} \mathrm{He}$ can copy handwriting, as he demonstrates at General Epančin's. He reproduces old Russian scripts, but also French and English ones; indeed he appears to actually overlay the Russian letters with a European style.

Then here I've written in a different script: it's the big, round French script of the last century; [...] it's a marketplace script, a public scrivener's script [...] you must agree, it's not without virtue. Look at these round d's and a's. I've

\footnotetext{
33 Numerous texts by Derrida support this idea. They argue against the preeminence of the present in Western metaphysics and hence, also, against the preeminence of the phonetic. Instead, Derrida accords a prominent position to the written word, the absent, the space between the characters. Two now-classic examples of this are: Jacques Derrida, 'Freud et la scène de l'écriture' (Derrida 1967); and Jacques Derrida, 'La différance' (Derrida 1972).

34 Adelaida reminds the prince in Part One that he still owes them the promised description of the "Basel picture", Ippolit takes up the description towards the end of Part Three (Dostoevsky 2003, 66, 407-408; Dostoevskij 1973a, 57, 338-339).

35 Ippolit also underscores this isolation (Dostoevsky 2003, 408; Dostoevskij 1973a, 339). It is caused not least by the fact that all of the spectators pitying and mourning Christ on the cross, and who are normally included in representations, are absent from Holbein's version. On Myškin's loneliness, which corresponds to the solitude of the dead Christ, cf. also Benjamin (1977, 238).

36 Dostoevsky himself practised calligraphy while writing the novel. Calligraphy is a key motif linked to the hero Myškin and one of the few themes that Dostoevsky had planned from the novel's inception (Miller 1998, 60).
} 
transposed the French characters ${ }^{37}$ into Russian letters, which is very difficult, but it came out well (Dostoevsky 2003, 33-34). ${ }^{38}$

Myškin does not only copy writing from the previous century, investing his letters with the souls of copyists and clerks, but also older handwriting, particularly that of the hegumen Pafnutij, a fourteenth century monk. Owing not least to the odd name Pafnutij, the whole scene is a play on Gogol's tale The Overcoat, on Akakij Akakievič and his writing skills. ${ }^{39}$ And as we know from Dostoevsky, all Russian writers are indebted to Gogol's Overcoat. But this intertextual intimation is etched not only into the letters of the novel; it is also inscribed in its objects and attire. Myškin is dressed in a sleeveless, foreign cloak with a large hood, which may keep him warm in Northern Italy and Switzerland, but certainly not in Russia (Dostoevsky 2003, 6, 136; Dostoevskij 1973a, 6, 115). The foreign Western letters, the contaminated Russian writing, the coat, also contaminated, and the nervous disorder finally converge in the name of Myškin's Swiss doctor, Šnejder (literally: tailor), who joins the ranks of Holbein the painter and Mejer, the owner of the wall. Šnejder was and is responsible for Myškin's psychological integrity, his mental garments. While he has been unable to cure the nervous disorder completely, he at least ensures that his patient is fit to travel. And Myškin is profoundly grateful to Šnejder. It was together with Šnejder that Myškin witnessed the guillotining of a criminal in Lyon. Has Myškin, then, received at the hands of Šnejder the same kind of psychological treatment, the same kind of moulding, to which Holbein subjects Christ? Has he been so westernised that he is unable to comprehend the Russian soul and the Russian God? There can be no question that Šnejder's course of treatment is reflected at least in Myškin's pity for the various condemned men and prisoners of the novel. Šnejder may even have fuelled Myškin's doubts about the divinity of Christ. Even contemporary readers were sure to have recognised Dostoevsky's dialogue with Gogol', recalling the negative, indeed devilish connotations of the tailor Petrovič. This intertextual trail invests the Swiss doctor Šnejder, the hero's foreign cloak, his handwriting samples, and the Holbein painting with a certain sinister nuance. It is as if there may be a yawning abyss inherent in modern psychology, comparable to the death of God. This abyss offers at least a glimmer of hope that something different, perhaps the Russian God, may lead the civilised, European consciousness out of the darkness. ${ }^{40}$

\footnotetext{
37 The English translation cited here suggests that the individual Latin letters were simply converted to Cyrillic. The Russian original refers to the French disposition, the French character itself, being conveyed in the Russian letters.

38 Dostoevskij (1973a, 29): “Потом я вот тут написал другим шрифтом: это круглый французский шрифт прошлого столетия, [...] шрифт публичных писцов [...]. Взгляните на эти круглые д, а. Я перевёл французский характер в русские буквы, что очень трудно, а вышло удачно."

39 Akakij's talent derives from the life of a saint (Seemann 1967). So it is no coincidence either that Myškin takes on the role of the monk Pafnutij.

${ }^{40}$ Knapp also points out that Dostoevsky's longing for a God-bearing Russian people only developed when he was in exile, and can accordingly be found, as a hope, in the novel he wrote in exile, The Idiot (Knapp 1998, 23). Dostoevsky is much more explicit about this desire in the Brothers Karamazov.
} 
And there is another sinister gap in the text, a trace that leads us back to the administration of justice. Myškins's father dies in jail. Why he was imprisoned, what crime he is accused of, whether his incarceration was the cause of his deathnone of this is explained. ${ }^{41}$ The trace-unimportant and extraneous to the plotdisappears. Such a total absence of any consequences is indicative of the modern penitentiary system, a type of power that is self-evident and self-reproducing. It is in this context that the narrator increasingly distances himself from the hero towards the end of the novel. The "better society" of the novel, the Epančin, Lebedev and Terent'ev families, also increasingly turn their backs on Myškin (Miller 1998, 96). The prince's growing isolation and confusion, his return to the Swiss asylum and presumably into Šnejder's care, again cause him to resemble Holbein's Christ, ${ }^{42}$ a lonely man condemned to death. Prisons and psychiatric institutions do not discharge their inmates, they simply perpetuate themselves.

Does Dostoevsky then prove to be a genuine European, even a Westernizer in The Idiot? He proves at least to be, just like Hans Holbein, a painter of the modern human mind, and he even expresses some criticism of this, his own art of the soul. ${ }^{43}$ There is an implicit grief in The Idiot, as in the Holbein painting, over the loss of God and the uncertainty of His existence, and Western psychology smacks of the devil's handiwork, of the Gogolian tailor Petrovič, or, to cite Foucault, of an allencompassing disciplinary power recognised as such. And yet this critical dimension also appears to be Western in character, describing precisely the European hospitals, asylums, and forms of punishment.

\section{Conclusion}

With the death penalty and imprisonment being renegotiated in post-Soviet Russia, Myškin's reflections and Ippolit's streams of vitriol possess a remarkable topicality. Civilisation, the ticket to Europe, and the Russian soul are back on the agenda.

It is no coincidence that Anatoly Pristavkin refers to The Idiot (as well as to other novels by Dostoevsky) when he describes the state of Russian prisons, individual crimes, and the work of the Pardons Commission. ${ }^{44}$ As with Dostoevsky, Pristavkin's review of the files may be described as ambivalent. He describes some of the criminals as unfortunates (Pristavkin, 2000a, 52) ${ }^{45}$ and reflects on the

\footnotetext{
41 Dostoevsky (2003, 96-97): “'My father died while he was on trial,' the prince observed again, 'though I could never find out precisely for what. He died in the hospital.'” Dostoevskij (1973a, 82): “—Отец мой ведь умер под судом,--заметил князь снова,-ххотя я и никогда не мог узнать, за что именно; он умер в госпитале."

42 Christ is initially surrounded by his disciples before being betrayed following his arrest. In the same way, Myškin is courted by various Petersburg families, only to ultimately return to Switzerland alone (Miller 1998, 88).

43 A view also held by Rosenshield.

44 Pristavkin (2000a, 347): “Тут самое время вспомнить Фёдора Достоевского Идиот” ("Now is the time to remember Fyodor Dostoevsky's The Idiot"). See also Pristavkin (2000c, 166).

45 The fact that criminals are known among the populace as "unfortunates" has led Dostoevsky, Alexander Herzen and other so-called Westerners or Slavophiles to identify a unique quality of the
} 
psychological state of the condemned person immediately after the sentence has been pronounced. His work is very much in the spirit of his literary predecessors Hugo and Dostoevsky (Pristavkin 2000a, 316-317). In other words, Pristavkin is guided by compassion. At times, however, the author has to force himself to actually be able to plead for the commutation of the death penalty to life imprisonment. It is impossible to ignore the brutality of the people, ${ }^{46}$ the unsavoury depths to which the "Russian soul" can $\operatorname{sink}^{47}$; this soul is in fact reduced to a wry abstraction (Pristavkin 2000c, 157).

Pristavkin criticises not only the death penalty, but also the prisons. His criticism owes much to Dostoevsky, even though modern Russian prisons are generally censurable for palpable shortcomings rather than disciplinary power and psychology (Pristavkin 2000a, 336). Benevolence and sophisticated psychology informed by European civilisation have no place in Russia, according to Pristavkin's sources. While the prisons may still have a lot of catching up to do, the prisoners evince a European awareness:

There is not even any money to renovate the buildings, we haven't received the prescribed meals allowance for three years now... We don't even have a dentist!

If you are not ashamed of yourself or ashamed to face the people, then at least be ashamed in the presence of the global community, especially the Council of Europe. ${ }^{48}$

Footnote 45 continued

Russian people, a typically Russian attitude towards crime. While they interpret this in different ways, they agree that it is not a matter of an abstract sense of justice. Dostoevsky uses the term frequently in The House of the Dead; Herzen in his famous letter to Michelet 1851: "Les déportés, les foréats se nomment dans la langue du peuple les malheureux." (Gercen 2010).

46 Pristavkin (2000a, 177): “самым страшным преступником оказывается народ, убивающий сам себя." ("The most terrible criminal of all turns out to be the people itself, which is killing itself.").

47 Pristavkin (2000a, 160): “Пили двое... Некий Герасимов [...] и его приятель. А когда последний отказался продолжать пить, встал и пошёл, Герасимов, обидевшись, нанёс ему удар ножом в спину, но лишь тяжело поранил [...].

Так вот она, загадочная, у русского человека душа. Но правда, кто-то однажды на Комиссии к этой фразе добавил: «И тело»."

"Two men were drinking together, a certain Gerasimov [...] and his friend. When his friend did not want to drink any more, he stood up and left. Gerasimov was offended and stabbed him in the back with a knife, injuring him seriously. [...]

So there we have it, the mysterious Russian soul. But, to tell the truth, someone in the Commission added once: 'And body'."

48 Pristavkin (2000b, 234): “даже на ремонт корпусов нет денег, продукты питания по рациону не получаем уже третий год... Даже зубного врача своего не имеем!

Не стыдитесь себя и своего народа, так хоть постыдитесь мирового сообщества, и прежде всего Совета Европы."

This prisoner believes that death itself is preferable to a sentence in the appalling Russian prisons, a view which lent itself to the title of the German translation of Pristavkin's 3-volume Russian treatise (Ich flehe um Hinrichtung, 'I implore you, execute me'). Another prisoner also describes Russian prisons as institutions of vengeance and not of punishment, because of their condition! (Pristavkin 2000b, 358) This view suggests that Russian prisons have effectively taken over the function of the death penalty. 
The words of this prisoner reveal the typically European discourse, initiated by Beccaria and developed by Dostoevsky, on civilisation and culture. A civilised form of punishment is demanded, the sign of civilisation is shame, shame is considered European. The fact that this civilisation may also include the possibility of state retribution can be verified by reading the Russian newspapers from November 2009 (Argumenty i fakty 2009, 8-9). Authors who oppose the death penalty invoke compliance with the law: Existing treaties, such as the agreement with the Council of Europe, must be adhered to. ${ }^{49}$ At the same time, they cite the possibility of miscarriages of justice ${ }^{50}$ and the psychological hardship of life imprisonment, particularly as no one is under any illusion as to the state of Russian prisons. ${ }^{51}$ But the opponents of such "leniency" also argue psychologically. They consider the long waiting periods for some condemned people in the USA unacceptable and believe that the penalty serves - again, psychologically-as a warning and a deterrent. ${ }^{52}$ Thus the post-Soviet debate about the meaning and purpose of the death penalty has all the hallmarks of a typically European discourse on civilisation, a discourse that Dostoevsky highlighted in The Idiot. For all his national aspirations, the poet of the Russian soul proves to be an extremely farsighted and critical European. It is indeed questionable whether the Russian soul could have been conveyed at all with the psychological tools of which Dostoevsky had such a masterful command.

\section{References}

Argumenty i fakty. (2009). November 47, pp. 8-9.

Bakhtin, M. M. (1929). Problemy tvorčestva Dostoevskogo. Leningrad: Priboj.

Bakhtin, M. M. (1963). Problemy poètiki Dostoevskogo. Moskva: Sovetskij pisatel'.

Benjamin, W. (1977). Der Idiot von Dostojewskij. In W. Benjamin, Gesammelte Werke (Vol. 2, 1, pp. 237-241). Frankfurt a. M: Suhrkamp.

Benz, E. (1988). Geist und Leben der Ostkirche. München: Wilhelm Fink Verlag.

Dalton, E. (1979). Unconscious structure in The Idiot. A study in literature and psychoanalysis. Princeton: Princeton University Press.

Dalton, E. (1989). Myshkin and Rogozhin. In D. Rancour-Laferiere (Ed.), Russian literature and psychoanalysis (pp. 89-99). Amsterdam, Philadelphia: John Benjamins.

Derrida, J. (1967). Freud et la scène de l'écriture. In J. Derrida, L'écriture et la différence (pp. 293-340). Paris: Edition du Seuil.

Derrida, J. (1972). La différance. In J. Derrida, Marges de la philosophie (pp. 1-29). Paris: Edition de Minuit.

Dostoevskij, F. M. (1973a). Idiot. Polnoe sobranie sočinenij v tridcati tomakh (Vol. 8). Leningrad: Nauka.

Dostoevskij, F. M. (1973b). Zimnie zametki o letnikh vpečatlenijakh. In F. M. Dostoevskij, Polnoe sobranie sočinenij $v$ tridcati tomakh (Vol. 5, pp. 46-98). Leningrad: Nauka.

\footnotetext{
49 Mikhail Barševskij is one of those who argue in this vein (Argumenty 2009, 9).

50 See also Pristavkin (2000a, 381).

51 This is the position of Vitalij Kvašis: “Для человека гораздо труднее-психологиче ски-узнать, что он никогда не выйдет из заключения. Тем более что в российских тюрьмах весьма суровые условия содержания." ("It is much harder-psychologically-for a person to know that he will never be released from jail. Especially as conditions in the Russian prisons are extremely severe.”) (Argumenty 2009, 8.) This view is reflected in the title of Barševskij's article: "Пусть гниют в тюрьме!" (“Let them rot in jail!") (Argumenty 2009, 9).

52 This is Jurij Antonjan's argument in Argumenty (2009, p. 8).
} 
Dostoevskij, F. M. (1981a). Dnevnik pisatelja za 1876 god. Polnoe sobranie sočinenij v tridcati tomakh (Vol. 22). Leningrad: Nauka.

Dostoevskij, F. M. (1981b). Dnevnik pisatelja za 1876 god. Polnoe sobranie sočinenij v tridcati tomakh (Vol. 23). Leningrad: Nauka.

Dostoevsky, F. M. (1973). Diary of a writer. New York: Octagon Books.

Dostoevsky, F. (2003). The Idiot. New York: Alfred A. Knopf.

Elias, N. (1978-1982). The civilizing process. Oxford: Basil Blackwell (original title: Über den Prozess der Zivilisation [1939; 2nd version: 1969]).

Foucault, M. (1991). Discipline and punish. The birth of the prison. London: Penguin Books (original title: Surveillance et punir [1975]).

Gercen, A. (2010). Le peuple russe et le socialisme. Lettre à Monsieur J. Michelet, 1851. http://az.lib.ru/g/gercen_a_i/text_0370.shtml. Cited July 6, 2010.

Hudspith, S. (2004). Dostoevsky and the idea of Russianness. A new perspective on unity and brotherhood. London: Routledge Corzon.

Jackson, R. L. (1993). Dialogues with Dostoevsky. The overwhelming questions. Stanford: Stanford University Press.

Knapp, L. (1998). When, where and how The Idiot was written. In L. Knapp (Ed.), Dostoevsky's The Idiot. A critical companion (pp. 3-26). Evanston: Northwestern University Press.

Kristeva, J. (1989). Holbein's dead Christ. Zone, 3, 238-269.

Kvashis, V. Y. (2002). Die Todesstrafe in Russland. In C. Boulanger, V. Heyes, \& H. Philip (Eds.), Zur Aktualität der Todesstrafe (pp. 357-374). Berlin: Berlin Verlag.

Martschukat, J. (2000). Inszeniertes Töten. Eine Geschichte der Todesstrafe vom 17. bis zum 19. Jahrhundert. Köln, Weimar, Wien: Böhlau.

Martschukat, J. (2005). Nineteenth-century executions as performances of law, death, and civilization. In A. Sarat \& C. Boulanger (Eds.), The cultural lives of capital punishment (pp. 49-68). Stanford: Stanford University Press.

Martschukat, J. (2006). Geschichte der Todesstrafe vom 17. bis zum 19. Jahrhundert. Wiesbaden: VMAVerlag.

Merežkovskij, D. (1909). L. Tolstoj i Dostoevskij. Žizn' i tvorčestvo. S.-Peterburg: Obščestvennaja proza.

Miller, R. F. (1998). The notebooks for “The Idiot”. In L. Knapp (Ed.), Dostoevsky's The Idiot. A critical companion (pp. 43-104). Evanston: Northwestern University Press.

Moeller van den Bruck, A. (1918). Dostojewski, der Nihilismus und die Revolution. In F. M. Dostojewski, Die Dämonen. Sämtliche Werke, Erste Abteilung: Fünfter Band (pp. VII-XXIII). München: Piper.

Nietzsche, F. (2009). Thus Spoke Zarathustra. Middlesex: Echo Library.

Onasch, K. (1996). Ikone. Kirche, Gesellschaft. Paderborn, Zürich: Ferdinand Schöningh.

Pristavkin, A. (2000a). Molenie o kazni. Dolina smertnoj kazni (Vol. 1). Moskva: Astrel' Olimp.

Pristavkin, A. (2000b). Strasti po Van'ke Kainu. Dolina smertnoj kazni (Vol. 2). Moskva: Olimp Astrel'.

Pristavkin, A. (2000c). Ne mogu byt’ bogom. Dolina smertnoj kazni (Vol. 3). Moskva: Olimp Astrel'.

Rosenshield, G. (2005). Western law, Russian justice. Dostoevsky, the jury trial and the law. Wisconsin: Wisconsin Press.

Said, E. (1979). Orientalism. New York: Vintage Books.

Schmid, U. (1999). Rogožins Hochzeitsnacht. In Dostoevsky studies, New Series (Vol. I, pp. 5-17).

Schrader, A. M. (1997). Containing the spectacle of punishment: The Russian autocracy and the abolition of the knout, 1817-1845. Slavic Review, 56 (4), 613-644.

Seemann, K.-D. (1967). Eine Heiligenlegende als Vorbild für Gogol's Mantel. Zeitschrift für Slavische Philologie, 33, 7-21.

Sergeyev, V. M. (1998). The wild east. Crime and lawlessness in post-communist Russia. Armonk, NY: M. E. Sharpe.

Spierenburg, P. (1984). The spectacle of suffering. Executions and the evolution of repression: From a preindustrial metropolis to the European experience. Cambridge: Cambridge University Press.

Vasenna, R. (2007). Reawakening national identity. Dostoevski's diary of a writer and its impact on Russian society. Bern: Peter Lang.

Wagner, H. (1995). Schuldspruch und staatliche Strafe im Werk Dostojewskis. In Stadt Baden-Baden, Kulturamt (Ed.), Fjodor M. Dostojewski (pp. 84-109). Baden-Baden: Nomos.

Weiß, V. (2005). Dostojewskijs "Dämonen”. Thomas Mann, Dmitri Mereschkowski und Arthur Moeller van den Bruck im Kampf gegen “den Westen”. In H. Kauffmann, H. Kellershohn, \& P. Jobst (Eds.), 
Völkische Bande. Dekadenz und Wiedergeburt-Analysen rechter Ideologie (pp. 90-122). Münster: Unrast.

Wesel, U. (1997). Geschichte des Rechts. Von den Frühformen bis zum Vertrag von Maastricht. München: Beck.

Wesel, U. (2004). Fast alles, was Recht ist. Jura für Nicht-Juristen. München.

Wolff, L. (1994). Inventing Eastern Europe. The map of civilization on the mind of the enlightenment. Stanford: Stanford University Press.

Zink, A. (2005). "Die Arrestanten waren die reinsten Kinder"-Zur Rechtfertigung des Verbrechens in Dostojewskijs Aufzeichnungen aus einem Totenhaus. In Dostoevsky studies, New Series (Vol. IX, 136-156). 